\title{
Salvage chemotherapy for metastatic germ cell tumours: The known unknowns
}

\author{
Aaron R. Hansen, MBBS, FRACP,; Philippe L. Bedard, MD, FRCPC ${ }^{* t}$ \\ *Princess Margaret Hospital, University Health Network, Division of Medical Oncology and Hematology, Toronto, ON; 'Department of Medicine, University of Toronto, Toronto, ON
}

See related article on page 111.

Cite as: Can Urol Assoc J 2012;6(2):117-8. http://dx.doi.org/10.5489/cuaj.12059

$\mathrm{H}$ igh-dose chemotherapy (HDCT) with autologous hematopoietic support in metastatic germ cell tumours (GCTs) has been investigated for over 25 years. Initial phase I/II studies achieved durable remissions with HDCT for a small subset of heavily pre-treated platinum-refractory patients with relapsed disease. ${ }^{1-3}$ Survival for metastatic GCTs has dramatically improved from 5\% in the early 1970 s to about $80 \%$ today. ${ }^{4,5}$ This improvement has been largely attributed to the advent of cisplatinbased chemotherapy and modern surgical techniques. The outcome for the $20 \%$ to $30 \%$ of metastatic GCTs whose disease relapses following cisplatin-based chemotherapy is much less favourable. Options for salvage therapy include conventional dose cisplatin-based chemotherapy (CDCT), with paclitaxel-ifosfamide-cisplatin (TIP) ${ }^{6}$ or etoposideifosfamide-cisplatin (VIP) ${ }^{7}$ or HDCT with autologous stem cell transplantation (ASCT). As initial therapy for patients with poor risk chemosensitive metastatic disease, upfront HDCT compared with CDCT has demonstrated no survival advantage in randomized trials. ${ }^{8-10}$ Whether HDCT is superior to CDCT as first-line salvage therapy for patients with relapsed disease is controversial. The only randomized trial conducted in this setting (European Group for Blood and Marrow Transplantation [EBMT]-IT-94) failed to showed superiority for three cycles of CDCT with VIP or vinblastine-ifosfamide-cisplatin (VeIP) followed by HDCT compared with four cycles of CDCT. ${ }^{11}$ However, there were methodological limitations to this study, such as the inclusion of cyclophosphamide, a drug with minimal activity in GCT, in the high-dose chemotherapy regimen and a lack of standardization for surgical and systemic treatment following progression.
Recently, the International Prognostic Factor Study Group (IPFSG) retrospectively reviewed data from 1984 patients with relapsed GCT previously treated with cisplatin-based combination chemotherapy. ${ }^{12}$ A five-category prognostic factor model was developed that reflected large differences in outcome, with progression-free survival (PFS) and overall survival (OS) at 2 years ranging from more than $70 \%$ in the most favourable group to less than $10 \%$ in the highest risk group. A subsequent retrospective analysis from the same group showed an improvement in PFS and OS in each prognostic group (with the exception of OS in the low-risk group) for upfront HDCT versus CDCT. ${ }^{13}$ In this issue of CUAJ, Beausoleil and colleagues provide a single institution retrospective analysis from the London Health Sciences Centre of 38 patients with relapsed GCT treated with first-line salvage chemotherapy with either four cycles of VIP/VelP as CDCT or three cycles of VIP/VelP followed by a single cycle carboplatin-based HDCT over a 20-year period. ${ }^{14}$ The authors' conclude that the IPFSG prognostic factor model performed similarly in their institutional dataset and that CDCT plus HDCT was superior to CDCT alone (2-year PFS $78 \%$ vs. $22 \%$; 5 -year OS $72 \%$ vs. $19 \%$ ). This study demonstrates that IPFSG model is applicable to a Canadian context and provides additional support for the use of HDCT as first-line therapy for appropriately selected patients with relapsed metastatic GCT. ${ }^{14}$

Retrospective comparisons of HDCT versus CDCT alone as first-line therapy for relapsed GCT are limited by several considerations: physicians may identify healthier patients who are able to tolerate HDCT compared with CDCT alone; the CDCT comparator group includes patients who were planned to receive HDCT after initial tumour debulking with CDCT, but never received HDCT because of toxicity or an inadequate therapeutic response; and the observed differences may be due to improvements in supportive care and surgical techniques for resection of residual masses that coincide with a greater proportion of patients receiving 
upfront HDCT compared with CDCT alone over time. An international randomized trial (TIGER) plans to randomize 390 patients to four cycles of CDCT with TIP compared with two cycles of paclitaxel-ifosfamide followed by three cycles of high-dose carboplatin and etoposide with autologous stem cell support (TI-CE). ${ }^{15}$ Whether this study will complete its planned accrual to definitely address this important question is unknown, as studies in metastatic GCTs have been increasingly difficult to conduct, due to the relative rarity of the patient population, ${ }^{16}$ the challenges of securing support for an international academic trial without a pharmaceutical sponsor, and the practice patterns of many institutions who have adopted HDCT as a first-line strategy based upon the existing non-randomized data.

Notwithstanding this lack of level I evidence in support of upfront HDCT for relapsed disease, there are many unanswered questions in the management of relapsed GCTs that may be addressed by non-randomized data analyses. These unanswered questions include: the optimal number of cycles of HDCT (one, two and three cycles have been used by different groups) with autologous stem cell support; if relapsing patients should proceed directly to HDCT upon diagnosis of relapse or if they should initially be treated with one to three cycles of induction CDCT to stabilize their disease and allow time to coordinate HDCT with autologous stem cell support with the transplant team; and if there are certain groups of patients with relapsed disease, such as patients with primary mediastinal non-seminoma or late ( $>2$ years) relapse that cannot be resected surgically, whose outcome is so poor that they should not be considered candidates for HDCT. What is clear, however, is that GCTs are unique as a metastatic solid malignancy that can be cured following relapse with additional chemotherapy. This medical imperative demands that all patients with relapsed GCT be managed in centres with specialized expertise. ${ }^{17-19}$

Competing interests: None declared.

This paper has been peer-reviewed.

\section{References}

1. Nichols $C R$, Tricot G, Williams SD, et al. Dose-intensive chemotherapy in refractory germ cell cancer-a phase $\mathrm{I} / \mathrm{II}$ trial of high-dose carboplatin and etoposide with autologous bone marrow transplantation. J Clin Oncol 1989;7:932-9.

2. Broun $E R$, Nichols $C R$, Kneebone $P$, et al. Long-term outcome of patients with relapsed and refractory germ cell tumors treated with high-dose chemotherapy and autologous bone marrow rescue. Ann Intern Med 1992; 117:124-8.
3. Siegert W, Beyer J, Strohscheer I, et al. High-dose treatment with carboplatin, etoposide, and ifosfamide followed by autologous stem-cell transplantation in relapsed or refractory germ cell cancer: a phase I/II study. The German Testicular Cancer Cooperative Study Group. J Clin Oncol 1994;12:1223-31.

4. LiMC, Whitmore WF, Golbey R, et al. Effects of Combined Drug Therapy on Metastatic Cancer of the Testis. JAMA 1960;174:1291-9. http://dx.doi.org/10.1001/jama.1960.03030100059013

5. Mead G, Stenning S, Parkinson MC, et al. The Second Medical Research Council study of prognostic factors in nonseminomatous germ cell tumors. Medical Research Council Testicular Tumour Working Party. J Clin Oncol 1992;10:85-94.

6. Kondagunta GV, Bacik J, Donadio A, et al. Combination of paclitaxel, ifosfamide, and cisplatin is an effective second-line therapy for patients with relapsed testicular germ cell tumors. J Clin Oncol 2005;23:6549-55. http://dx.doi.org/10.1200/JC0.2005.19.638

7. McCaffrey JA, Mazumdar M, Bajorin DF, et al. Ifosfamide-and cisplatin-containing chemotherapy as first-line salvage therapy in germ cell tumors: response and survival. J Clin Oncol 1997;15:2559-63.

8. Motzer RJ, Nichols CJ, Margolin KA, et al. Phase III randomized trial of conventional-dose chemotherapy with or without high-dose chemotherapy and autologous hematopoietic stem-cell rescue as first-line treatment for patients with poor-prognosis metastatic germ cell tumors. J Clin Oncol 2007;25:247-56. http://dx.doi.org/10.1200/JC0.2005.05.4528

9. Droz JP, Kramar A, Biron P, et al. Failure of high-dose cyclophosphamide and etoposide combined with double-dose cisplatin and bone marrow support in patients with high-volume metastatic nonseminomatous germ-cell tumours: mature results of a randomised trial. Eur Urol 2007;51:739-46; discussion 747-8. http://dx.doi.org/10.1016/i.eururo.2006.10.035

10. Daugaard G, Skoneczna I, Aass N, et al. A randomized phase III study comparing standard dose BEP with sequential high-dose cisplatin, etoposide, and ifosfamide (VIP) plus stem-cell support in males with poorprognosis germ-cell cancer. An intergroup study of EORTC, GTCSG, and Grupo Germinal (EORTC 30974). Ann Oncol 2011;22:1054-61. http://dx.doi.org/10.1093/annonc/mdq575

11. Pico JL, Rosti G, Kramar A, et al. A randomised trial of high-dose chemotherapy in the salvage treatment of patients failing first-line platinum chemotherapy for advanced germ cell tumours. Ann Oncol 2005;16:1152-9. http://dx.doi.org/10.1093/annonc/mdi228

12. Lorch A, Beyer J, Bascoul-Mollevi C, et al. Prognostic factors in patients with metastatic germ cell tumors who experienced treatment failure with cisplatin-based first-line chemotherapy. J Clin Oncol 2010;28:490611.

13. Lorch A, Bascoul-Mollevi C, Kramar A, et al. Conventional-dose versus high-dose chemotherapy as first salvage treatment in male patients with metastatic germ cell tumors: evidence from a large international database. J Clin Oncol 2011;29:2178-84. http://dx.doi.org/10.1200/JC0.2010.32.6678

14. Beausoleil M, Ernst DS, Stitt L, et al. Consolidative high-dose chemotherapy after conventional-dose chemotherapy as first salvage treatment for male patients with metastatic germ cell tumours. Can Urol Assoc J 2012;6:111-6. http://dx.doi.org/10.5489/cuaj.11233

15. Feldman D, Huddart R, Hall E, et al. Is High Dose Therapy Superior to Conventional Dose Therapy as Initial Treatment for Relapsed Germ Cell Tumors? The TIGER Trial. J Cancer 2011;2:374-7. http:// dx.doi.org/10.7150/ica.2.374

16. de Wit R, Skoneczna I, Daugaard G, et al. Randomized Phase III Study Comparing Paclitaxel-Bleomycin, Etoposide, and Cisplatin (BEP) to Standard BEP in Intermediate-Prognosis Germ-Cell Cancer: Intergroup Study EORTC 30983. J Clin Oncol 2012;30:792-9. Epub 2012 Jan 23.

17. Schmoll HJ, Souchon R, Krege $S$, et al. European consensus on diagnosis and treatment of germ cell cancer: a report of the European Germ Cell Cancer Consensus Group (EGCCCG). Ann Oncol 2004;15:1377-99. http://dx.doi.org/10.1093/annonc/mdh301

18. Krege $S$, Beyer J, Souchon R, et al. European consensus conference on diagnosis and treatment of germ cell cancer: a report of the second meeting of the European Germ Cell Cancer Consensus group (EGCCCG): part I. Eur Urol 2008;53:478-96. http://dx.doi.org/10.1016/i.eururo.2007.12.024

19. Wood $L$, Kollmannsberger $C$, Jewett $M$, et al. Canadian consensus guidelines for the management of testicular germ cell cancer. Can Urol Assoc J 2010;4:e19-38.

Correspondence: Dr. Philippe Bedard, Princess Margaret Hospital - University Health Network, Division of Medical Oncology and Hematology, Princess Margaret Hospital, 5-125 - 610 University Ave., Toronto, ON M5G 2M9; philippe.bedard@uhn.ca 